I Universidade de Brasília (UnB), Programa de Pós-Graduação

em Antropologia Social, Brasília, Brasil

msjoaomiguel@gmail.com

João Miguel Sautchuk'

\title{
MÚSICA E VIDA SOCIAL NA ANTROPOLOGIA DE ANTHONY SEEGER
}

\author{
Seeger, Anthony. (20I5). \\ Por que cantam os Kĩsêdjê: uma antropologia musical \\ de um povo amazônico. \\ São Paulo: Cosac Naify, 320 p.
}

O livro versa sobre a música na vida dos Kĩsêdjê, grupo indígena de língua jê que vive no estado do Mato Grosso, e pergunta pelo valor do canto e das cerimônias nessa sociedade, pelas estruturas das performances musicais e pelo modo como a música está ligada à reprodução de identidades e papéis sociais. As análises baseiam-se na experiência etnográfica de Seeger com os Kĩsêdjê nos anos I97I, I972 e I 976. Com o título Why Suyá sing: a musical anthropology of an Amazonian people, o livro foi publicado originalmente em inglês, em I 987 (com segunda edição em 2004). Só recentemente, quase três décadas depois, foi traduzido para a edição brasileira, com a alteração do título para Por que cantam os Kĩsêdjê, em respeito à atual preferência do grupo por essa autodenominação.
Por que cantam os Kĩsêdjê é obra relevante para os estudos sobre sociedades indígenas na América do Sul (sobre os povos de língua jê, especificamente), traz contribuições para a análise antropológica de rituais e é fundamental para a etnomusicologia. Ao lado dos trabalhos de antropólogos e etnomusicólogos como Rafael Menezes Bastos (I 978; 2013), Steven Feld (I982), Ruth Stone (I98I) e Charles Keil (I979), apresenta perspectiva renovada para esse campo, pautando no estudo das práticas musicais o foco nas ações, na visão (ou teoria) nativa e nas relações entre elas.

Sem resvalar para qualquer dogmatismo novidadeiro, Seeger propõe um deslocamento conceitual sutil, mas de consequências decisivas para seu enquadramento analítico. Afirma que seu trabalho consiste não em uma "antropo- 
logia da música", mas em uma "antropologia musical”. A primeira, em seu momento de consolidação nas décadas de I950 e I960, estaria demasiadamente preocupada com os produtos sonoros tomados em si e com o esforço para demonstrar aspectos sociais e culturais das músicas. A segunda pensa "a vida social como performance" (p. I4) e busca compreender a "música" (atentando para a relatividade do termo) como processo, interação e conhecimento. Ou seja, indo um bocado além de situar a música como parte da cultura, propõe entender a vida social a partir do fazer musical, captando os modos pelos quais as performances criam e recriam diversos aspectos da cultura e da sociedade. As inspirações indicadas nesse sentido são as teorias e abordagens da prática de Sahlins, Herzfeld, Giddens e Bourdieu, sutilmente absorvidas por Seeger.

Contribui para essa proposta de uma antropologia musical a própria composição narrativa do livro, que tem como fio condutor a análise da Festa do Rato, ritual kĩsêdjê de nominação e iniciação masculinas, de que Seeger participou em 1972 e i976. A narrativa fluida do cotidiano e das cerimônias, das relações estabelecidas pelos índios com o pesquisador e sua esposa, Judith, e dos preparativos para a festa (as conversas entre homens no pátio, o aprendizado de uma nova canção, uma expedição de caça e a distribuição de alimentos) conduz à compreensão de elementos fundamentais da vida social kĩsêdjê, como sua organização social e sistema de parentesco, a sazonalidade das atividades coletivas, a cosmologia e a concepção de espaço. Diversos desses temas foram abordados pelo autor em trabalhos anteriores (Seeger, I980) e reaparecem alinhavados pela análise dos rituais e sua música.

A Festa do Rato diz respeito fundamentalmente à socialização das crianças. Dramatiza ações do mito em que um rato oferece milho (alimento até então desconhecido) para uma mulher e seu filho pequeno, e o menino posteriormente oferece beiju de milho aos homens no pátio da aldeia. A realização do rito reproduz delineamentos identitários a partir das relações de autoridade e reciprocidade e das oposições espaciais (entre casa e pátio, consanguinidade e afinidade, aldeia e floresta, natureza e cultura) e de papéis no rito. A festa dura cerca de quinze dias ao longo dos quais aprendizado e preparação produzem crescente dramaticidade. Num dos momentos centrais da cerimônia, os homens (de todas as idades), reunidos no pátio da aldeia, dançam e cantam ao mesmo tempo cada um sua canção para ser ouvidos por suas respectivas irmãs, que permanecem no interior das casas.

Para entender a eficácia do cerimonial kĩsêdjê é necessário compreender suas formas expressivas, sobretudo dos cantos. Nesse ponto, exercitando uma das lições mais preciosas do estruturalismo, a de que definições e significados surgem pelas diferenciações sistêmicas em um conjunto, Seeger compreende a música kĩsêdjê em contraste com outras atividades e outras formas de arte (p. 67). O resultado é uma análise inspiradora, de notável sofisticação analítica e sensibilidade etnográfica. O contraste principal se dirige aos gêneros vocais, 
como as diversas categorias de fala, as narrações míticas e instruções dos mais velhos aos mais jovens, as invocações nos ritos de cura e as formas do canto. Embora não tenham formulações sistemáticas a respeito, os Kĩsêdjê diferenciam enfaticamente essas categorias. $\mathrm{Na}$ análise formal, Seeger percebe que, em contraste com a fala cotidiana, oratória, canto e instrução são musicais pela elaboração de tempo, timbre e melodia, porém, não são todos compreendidos pelos Kĩsêdjê como "música” (p. IOI). Seeger compreende esses aspectos formais em função de seus usos e significados sociais e da classificação nativa, percebendo critérios relativos de prioridade da melodia sobre o texto (ou o inverso), modo mais ou menos fixo de apresentação, quem profere e em que situação, redundância de elementos textuais, duração relativamente fixa das frases, relações tonais estruturadas e autoridade de seus textos fixos (p. I I4).

As canções se distinguem dos demais gêneros verbais kĩsêdjê também por sua origem sempre externa à sociedade: são aprendidas com estrangeiros (os brancos e outros indígenas) ou com espíritos animais. Como em muitas outras sociedades indígenas da América do Sul, o canto indica metamorfose. Na Festa do Rato, misturam-se as temporalidades do mito e do presente (p. 229). De tanto cantar, homens transformam-se em ratos - por exemplo, quando os homens cantam sobre um menino exortando-o a fazer parte da comunidade masculina que se reúne na casa dos homens, presentificando a ação do rato no mito. Já as mulheres dão de comer a seus irmãos e filhos casados (o que no cotidiano é feito pelas esposas), refazendo as relações de comensalidade descritas no mito. Assim, o canto enfatiza as identidades sociais e concretiza a força criadora e socializadora das cerimônias.

A resposta à questão colocada no título do livro, portanto, desvia-se de qualquer ambição de encontrar causas últimas para os comportamentos. Ao contrário, busca os significados do canto para os Kĩsêdjê como caminho para apontar a eficácia dos rituais na criação e recriação da ordem do mundo.

As edições anteriores (em inglês) eram acompanhadas de gravações sonoras em fita e CD. A edição brasileira vem acompanhada de um DVD que acrescenta a esse material importantes registros audiovisuais, dentre os quais vale ressaltar o documentário Amtô, sobre a Festa do Rato, produzido e dirigido pelos Kĩsêdjê e editado pelo Vídeo nas Aldeias (20I I). Ali, questões abordadas no texto do livro, como a diferença de perspectivas sobre a festa entre homens e mulheres, as diferenças de percepção e apreciação do rito entre brancos e kĩsêdjês e a metamorfose ritual de homens em ratos, ressoam com intensidade ímpar. A edição brasileira traz ainda adaptação dos nomes e termos indígenas à grafia adotada pelos Kĩsêdjê, algumas retificações de dados etnográficos e um novo posfácio com reflexões sobre as transformações históricas e a condição atual dos Kĩsêdjê. Digno de nota, os direitos autorais da edição brasileira, assim como das anteriores, são destinados aos Kĩsêdjê.

Recebida em 7/2/2018 Aprovada em I4/2/20I8 


\section{REFERÊNCIAS BIBLIOGRÁFICAS}

Feld, Steven. (1982). Sound and sentiment: birds, weeping, poetics and song in Kaluli expression. Philadelphia: University of Pennsylvania Press.

Keil, Charles. (I979). Tiu song. Chicago: University of Chicago Press.

Menezes Bastos, Rafael José de. (2013). A Festa da Jaguatirica: uma partitura crítico-interpretativa. Florianópolis: Ed. UFSC.

Menezes Bastos, Rafael José de. (1978). A musicológica Kamayurá: para uma antropologia da comunicação no Alto Xingu. Brasília: Funai.

Seeger, Anthony. (1980). Os índios e nós: estudos sobre sociedades tribais brasileiras. Rio de Janeiro: Campus.

Stone, Ruth. (I98I). Toward a Kpelle conceptualization of music performance. The Journal of American Folklore, 94/372, p. I88-206.

João Miguel Sautchuk é antropólogo formado pela Universidade de Brasília (UnB). Seus principais temas de pesquisa são análise antropológica de rituais, cultura popular, construção da nação, etnomusicologia e etnografia das práticas. Seus principais trabalhos publicados são A poética do improviso: prática e habilidade no repente nordestino, "Interesse moderno pelo folclore: nação e cultura no Mapa Musical do Brasil da gravadora Marcus Pereira" e (com Carlos Sautchuk) "Enfrentando poetas, perseguindo peixes: sobre etnografias e engajamentos". 